Joanna Majewska-Zarychta*

\title{
DWUBIEGUNOWOŚĆ POSTAW WOBEC ZJAWISKA MIGRACJI I ICH ODZWIERCIEDLENIE W JĘZYKU DYSKURSU MEDIALNEGO
}

\section{Wprowadzenie}

Tematem artykułu jest analiza postaw wobec migracji, które można zaobserwować wśród środowisk społecznych i politycznych. Postawy te są skoncentrowane na dwóch skrajnych biegunach. Dwubiegunowość wyraża się w wypowiedziach środowisk prawicowych i lewicowych. W celu zaprezentowania zagadnienia zostanie przedstawiona definicja postawy i jej komponenty (poznawczy, behawioralny i emocjonalny). Następnie zostaną omówione stereotypy związane z postawą negatywną wobec zjawiska migracji. Główny cel artykułu zostanie zrealizowany w kolejnym etapie poprzez zaprezentowanie przykładów wpisujących się w dwubiegunowość postaw. Artykul kończy podsumowanie, zawierające najważniejsze wnioski.

\section{Definicja postawy w ujęciu psychologicznym i jej komponenty}

Postawa jest to pojęcie wieloznaczne i ma wiele sposobów definiowania. Pierwsza definicja pochodzi od filozofów $\mathrm{H}$. Spencer i A. Baina, według których jest to stan umysłu, „psychiczny stan gotowości do słuchania oraz uczenia się czegoś" (Ceranek-Dadas i Neuman-Schmidtke 2005: 743-749). Postawa podobnie jest definiowana przez psychologów. Jednym z przedstawicieli nurtu psychologicznego jest G.W. Allport. Według niego postawa jest „psychicznym i nerwowym stanem gotowości, zorganizowanym przez doświadczenie, wywierającym ukierunkowujący lub dynamiczny wpływ na reakcje jednostki w stosunku do wszystkich przedmiotów czy sytuacji, z którymi jest on związany"

* Mgr Joanna Majewska-Zarychta, Katolicki Uniwersytet Lubelski Jana Pawła II. 
(Mądrzycki 1977: 13). Inni psychologowie, tym razem przedstawiciele teorii poznawczych szczególne zainteresowanie kierują na wewnętrzną strukturę postaw i wzajemne relacje między jej komponentami. Przykładem jest definicja D. Krecha i R.S. Crutchfielda, według których postawa jest „trwałą organizacją procesów motywacyjnych, emocjonalnych, percepcyjnych i poznawczych, związanych z jakimś aspektem świata jednostki” (Mądrzycki 1977: 13-14). Spośrod trzech komponentów: poznawczego (przekonania oceniające), uczuciowego (negatywne lub pozytywne uczucia) i behawioralnego (dyspozycje działania negatywnego lub pozytywnego), które składają się na postawę, wiodącą rolę w powyższej koncepcji pełni komponent poznawczy. Zmiana elementu poznawczego zmienia uczucia jednostki i jej tendencję do działania (Mądrzycki 1977: 14).

Ta strukturalna koncepcja postaw, składająca się z trzech komponentów, została zaakceptowana zarówno przez psychologów behawioralnych, jak i poznawczych. Postawa składa się zatem z następujących komponentów: poznawczego (obejmującego myśli, wiedzę, przekonania), behawioralnego i emocjonalnego (uczucia i emocje).

W literaturze wyróżnia się trzy znaki postawy: dodatni $(+)$ - postawa przychylna; ujemny $(-)$ - postawa nieprzychylna; zerowy (0) - postawa neutralna (Fidelus 2011: 100). Postawa jest względnie trwała i złożona. Postawa może się zmienić pod wpływem mechanizmu ulegania, identyfikacji z osobą lub grupą, której chcemy się przypodobać oraz internalizacji, czyli uwewnętrznieniu wartości. Uleganie następuje pod wpływem władzy, jaką dysponuje osoba, która wywiera wpływ. W przypadku identyfikacji decydująca jest atrakcyjność osoby, z którą się utożsamiamy, a w przypadku internalizacji strategiczna jest wiarygodność osoby, która dostarcza informacje (Aronson 2009: 44-45).

W kontekście postaw należy powiedzieć także o roli stereotypu, który jest bardzo silną i sztywną postawą. Stereotyp jest zatem pierwszą uwzględnioną w tym artykule kategorią analityczną. T.D. Nelson (2003: 28) sądzi, że stereotypy to postawy międzygrupowe, które zawierają komponent afektywny, behawioralny i poznawczy. Zawierają zatem wszystkie komponenty struktury postawy. Na ich podstawie tworzą się uprzedzenia. Granice pomiędzy stereotypami i uprzedzeniami są nieostre, wiążą się ze sobą nawzajem. Zastanówmy się zatem, skąd pochodzą stereotypy. Irena Pospiszyl uważa, że „korzenie stereotypów tkwią w niewiedzy, a korzenie uprzedzeń w podświadomości” (Pospiszyl 2009: 54). Stereotypy biorą się z silnych emocji, kształtują bez udziału indywidualnego, dotyczą przedstawicieli innych kultur, religii, latwo się utrwalają i są bardzo odporne na zmiany. Są przekazywane za pośrednictwem języka (Mądrzycki 1977: 13). Chodzi tu o negatywne sądy bezpodstawnie formułowane na temat osób innej rasy, religii, kultury, które nie są oparte na indywidualnym doświadczeniu, lecz na irracjonalnym myśleniu. Jednostka nie dąży do ich weryfikacji. Należy tu wspomnieć o hipotezie kontaktu Allporta z 1954 r., która 
jest strategiczna w stereotypach. Osoby, które nie mają lub nie miały kontaktu z kimś, kto jest pod jakimś względem inny, mają szereg wyobrażeń na temat obcych osób; te sądy zaszczepily od rodziny, znajomych, mediów, źródłem ich mogą być również doświadczenia historyczne (Markowska-Manista 2017: 113-129).

Postawa jest ważnym elementem komunikacji międzykulturowej. Proces komunikacji międzykulturowej może być wyzwalany, jak i hamowany za pośrednictwem stereotypów (Markowska-Manista 2017: 113-129). Polska była kiedyś krajem monokulturowym i monoetnicznym, jednak wstąpienie do Unii Europejskiej otworzyło drogę do współpracy i komunikacji międzynarodowej, rozpoczał się wówczas proces integracyjny, którego udziałem jest spotkanie z innymi kulturami i religiami.

\section{Postawa pro i contra migracji}

Ponieważ postawa jest trwałą organizacją procesów motywacyjnych, emocjonalnych, percepcyjnych i poznawczych obejmuje zarówno sądy, motywację, jak i uczucia. Biorąc pod uwagę znaki, jakie wyróżniono w postawie, w dyskursie medialnym można zauważyć postawę o znaku dodatnim oraz postawę o znaku ujemnym. Innymi słowami, można je określić jako postawy pro i contra migracji. Jednym z przykładów pro migracji są wypowiedzi noblistki Olgi Tokarczuk. Jej wypowiedź jest następująca:

Spotkanie z dziećmi było cudowne, one są tak kolorowe. Pomyślałam, jakie bogactwo Szwecja sobie przygarnęła wraz z imigrantami, jaki potencjał wrażliwości i puli genetycznej. Zawsze w takich momentach jest mi wstyd za ten straszny 2014 rok, kiedy Polska nie przyjęła imigrantów. Nigdy nie potrafię tego zrozumieć. (Tokarczuk 2019).

Jednak stanowisko polskiego rządu wobec polityki proimigracyjnej jest nieustępliwe, a rzecznik rządu nie zgadza się na nową politykę migracyjną ani na przymusową relokację uchodźców. Kościołowi zarzuca się szerzenie nienawiści w stosunku do imigrantów i strach przed tym, co inne. W mediach prawicowych zachodzi zjawisko tzw. „globalno-lokalnej paniki medialnej wokół uchodźców" (Samoniuk 2017: 15), które opiera się na obrazie uchodźcy nasyconym negatywnymi wyrażeniami. Media są wręcz katalizatorem lęku społecznego. Dwa konkurencyjne obrazy imigrantów są źródłem dwóch różnych skrajnych postaw w stosunku do współczesnego problemu migracji. Barbara Samoniuk (2017: 16) określa panikę medialną jako problem moralny, należy rozstrzygnąć, kto ma pomóc uchodźcom w zaistniałej sytuacji. Te dwa obrazy uchodźcy są oparte na silnych emocjach, schematach poznawczych i różnych wartościach moralnych. 
Wzrost niechęci, czy nawet nienawiści do uchodźców w polskim społeczeństwie jest związany z obawą o bezpieczeństwo ekonomiczne, społeczne, kulturowe, potencjalne zamachy, obawą przed wpływem islamu na religię chrześcijańską, konkurencją na rynku pracy. Leksem „uchodźca” kojarzy się z zagrożeniem dla polskiej tożsamości, konfliktami na tle religijnym i chęcią wyparcia chrześcijaństwa z Europy. Jest to fobia przed imigrantami z Bliskiego Wschodu i północnej Afryki, którą można określić jako islamofobię i ksenofobię. Zastanówmy się, co kształtuje niechęć i nienawiść Polaków do imigrantów, jakie są jej przejawy.

\section{Dwubiegunowość postaw a stereotypy}

Osoby o steretypowych postawach często nigdy nie miały kontaktu z inną nacją. Osoba o takiej postawie generalizuje i przypisuje wszystkim przedstawicielom danej nacji negatywne cechy. Emocje towarzyszące takiej osobie to lęk, nienawiść, wrogość, antypatia. To bezkrytyczne i bezrefleksyjne etykietowanie jednostek jest oparte na podziale „my” i „oni”. My jesteśmy ci lepsi, a oni ci gorsi. Podział na „my” i „oni” jest związany z drugą zaakcentowaną w tym artykule kategorią analityczną, mianowicie obcością. Dychotomiczny podział wywodzi się niewątpliwie z intelektualnego lenistwa i utożsamiania się z określoną grupą społeczną. Potrzeba identyfikacji z grupą jest bardzo silna, dlatego osoba jest w stanie poświęcić własne zdanie po to, aby być w grupie, aby za wszelką cenę nie zostać z niej wykluczoną. Ta dychotomia widoczna jest w słowach Artura Domosławskiego:

My, Polacy, przeskoczyliśmy do Pierwszego Świata. Dla uchodźców jesteśmy krezusami. I nie chcemy się dzielić. Jesteśmy biedniejsi od Szwajcarów czy Francuzów, a mimo to należymy do światowej elity materialnej. Większość ludności świata jest biedniejsza niż Polacy. Należymy w tej chwili do elitarnego klubu krajów bogatych, nawet jeśli nie zdajemy sobie $\mathrm{z}$ tego sprawy. A zarazem jesteśmy jednym $\mathrm{z}$ tych państw, które najmniej łożą na biednych. (Domosławski i Gostkiewicz 2016).

W swojej książce „Wykluczeni” Domosławski przedstawia portret globalnego Południa, „biednego, wykorzystywanego przez nas Europejczyków”. Aktualna fala uchodźców to „Wielka Wędrówka Ludów, to uwertura do symfonii. Zacznijmy myśleć, że musimy się posunąć, by zrobić im miejsce”. W artykule wysuwane są także kontrargumenty do chęci pomocy uchodźcom, w następujący sposób: „Są inni od nas i groźni”; „Lubią nasze kobiety!”; „Roznoszą choroby!”; „To terroryści!”. W takich sformułowaniach widoczne są stereotypy, które są przekazywane za pomocą języka i kształtują negatywny obraz uchodźców jako dzikusów i intruzów. Imigranci przeżywają falę hejtu, także ze względu na ich biedę, niechęć do przystosowania się, ataki terrorystyczne, a nawet to, że mówią innym językiem niż europejskim i mają ciemniejszy kolor skóry (Domosławski i Gostkiewicz 2016). 
Inne wypowiedzi, w których widać dychotomię „my” i „oni” we fragmentach: my jesteśmy w stanie przyjąć więcej uchodźców. (Piasecki 2015).

„Oni” są biedni, bo my jesteśmy bogaci. (Kapela 2015).

To my jesteśmy prezentem dla Europy, korzystają z naszego rynku zbytu ${ }^{1}$.

Uchodźcy są zmuszeni do opuszczenia swoich krajów i to my jesteśmy za to odpowiedzialni. (...) Jeśli ci ludzie uciekają przed biedą, wojną, prześladowaniem i śmiercią, przybywają tu, prosząc o schronienie, to nie możemy im odmawiać, nie możemy zapominać, kim sami kiedyś byliśmy².

Wszystkie te wypowiedzi wiążą się ze wspomniną paniką medialną, która rozpoczęła się w $2015 \mathrm{r}$. Za pomocą sformułowania „Europę zalewa fala uchodźców"; a był to synonim zagrożenia społecznego, ekonomicznego i kulturowego Europy; uchodźcy byli przedstawiani jako „folks devils”. W wyniku szerzenia się rasizmu, ksenofobii i mowy nienawiści, poglądy konserwatyne zderzyły się z poglądami osób otwartych, liberalnych. Uchodźcy stali się wrogiem numer jeden, w dyskursie antymigracyjnym określani byli jako agresorzy: „To najeźdźcy nie uchodźcy” (Do Rzeczy), „Piekło na rozkaz Berlina” (W Sieci), „90 tysięcy Arabów zaleje Polskę" (Super Expres). Niedługo potem doszło do zamachów, które utwierdziły społeczeństwo polskie w przekonaniu o słuszności tych sformułowań. Wyrażenia typu „fala uchodźców”, „rzeka uchodźców”, „nurt uchodźców” kojarzone $\mathrm{z}$ katastrofą naturalną zapisały się w długotrwałej pamięci Europejczyków. Tego typu określenia odebrały uchodźcom twarze, stali się bezosobową masą, bez imion, nazwisk, marzeń. Ta depersonalizacja widoczna była zarówno w mediach prawicowych, jak i lewicowych. Ogromny wplyw na świadomość miały następujące po sobie zamachy terrorystyczne. Niechęć wobec uchodźców wzrastała. W roku 2015 mamy $21 \%$, a w roku 2016 mamy $61 \%$ osób niechętnych imigracji. Eskalacja niechęci wiąże się nierozerwalnie z utrwalaniem stereotypu uchodźcy jako osoby brutalnej, agresywnej, niebezpiecznej. Uchodźca kojarzony $\mathrm{z}$ terroryzmem jest niechętnie widziany w Polsce. Wracając do tematu homogeniczności i heterogeniczności etnicznej, należy powiedzieć o tym, że społeczeństwa heterogeniczne etnicznie są bardziej otwarte na politykę proimigracyjną,

1 Wkrótce do Słowackiego „nie” dołączą inni premierzy. Czy po wyborach PIS zmieni ustalenia dotyczące uchodźców? https://www.newsweek.pl/polska/po-i-pis-kl oca-sie-o-uchodzcow-w-polsce/k89trhl [Dostęp: 12.12.2019].

2 https://www.polsatnews.pl/wiadomosc/2019-08-25/uchodzcy-sa-zmuszen i-do-opuszczenia-swoich-krajow-i-to-my-jestesmy-za-to-odpowiedzialni/ [Dostęp: 12.12.2019]. 
azylową, propagowaną przez partie liberalne i lewicowe, chętniej zaakceptują imigranta jako sąsiada albo współpracownika. A postawa Polaków nie jest zakotwiczona $\mathrm{w}$ wielokulturowości, ma niewiele doświadczeń $\mathrm{z}$ islamem. Homogeniczność/heterogeniczność jest trzecią kategorią analityczną, ważną z punktu widzenia językowej analizy problematyki migracji. W związku z tym heterogeniczność etniczna wpływa na pozytywny stosunek do tematu uchodźców (Pasamonik i Markowska-Manista 2017: 21).

Wizerunek uchodźcy pokazywany w mediach oparty na selektywnych informacjach sprowadza się do „najeźdźcy” niechętnego do integracji, pójścia na żadne kompromisy, który ucieka z kraju wojny (Syrii), próbującego za wszelką cenę dotrzeć do Niemiec - kraju kojarzonego z socjalnym rajem. To tutaj według krytyków imigracji tworzą się dzielnice muzułmańskie, tętniące własnym, niebezpiecznym życiem. Zagrożenie jest analizowane w szerokim zakresie poziomów życia społecznego i stanowi czwartą kategorię analityczną. Kraje, z których pochodzą uchodźcy są przedstawiane jako skrajnie biedne, nie ma tam pozytywnych perspektyw ekonomicznych przy występującym wysokim poziomie bezrobocia. Media lewicowe mówią, że wystarczy dać pracę uchodźcom, pieniądze, lepsze szkoły, a problem terroryzmu zaniknie samoistnie. Jednak przykład Londynu pokazuje, że to nieprawda. Wielu wykształconych muzułmanów wybiera ISIS. Dopóki będzie istnieć ISIS, dopóty głowy muzułmanów będą pod jego wpływem, ponieważ „Państwo Islamskie to produkt również duchowy” (Orzechowski 2018: 159). Według Marka Orzechowskiego nawet, gdy ISIS zniknie z mapy świata, nadal będą widoczne jego wpływy, gdyż zwerbowani do tej „organizacji” terroru i śmierci „wojownicy” nadal będą rozprzestrzeniać niepokój społeczny. Wydarzenia, które ukształtowały obraz uchodźcy jako „islamisty” dowodzą, że ataki terrorystyczne to nie przypadki, lecz rodzaj wojny toczonej z całym światem. Sceny pokazywane w mediach, w których islamiści dokonują brutalnych egzekucji, np. obcinanie głów, języków, wydłubywanie oczu, amputacje kończyn, zrzucanie ze skały, wpisały się głęboko w świadomość i podświadomość Polaków. Aż trudno uwierzyć, że są oni bezradnymi ofiarami, które potrzebują pomocy. Za wojną w Syrii stoją sprzeczne interesy wielu państw. Agresja sfrustrowanych muzułmanów przenosi się na kraje europejskie, które nie mają narzędzi, aby ją wyciszyć, aby zintegrować tak ogromną liczbę osób. Ta niebezpieczna sytuacja będzie przyczyną wielu konfliktów w Europie, która na własne życzenie zgotowała mieszkańcom „Piekło na życzenie Berlina” (W Sieci). W Polsce reakcją na falę uchodźców była manifestacja z 12.10.2015 r. „Polacy przeciw imigrantom”, która rozpowszechniała hasła, typu „Polska dla Polaków”, „Stop islamizacji Polski”, „Islam to śmierć” oraz „Uchodźcy muzułmańscy to koń trojański dla Europy”. W tym samym czasie odbyła się kontrmanifestacja „Uchodźcy mile widziani”, popierająca islamizację Europy. Wiele osób wzięło udział w manifestacji „Dzień solidarności z uchodźcami”, w której odezwie można przeczytać: „W tym dniu chcemy powiedzieć wszystkim, którzy uciekają ze swojej ojczyzny przed wojną, 
chaosem, głodem, pożogą i nędzą: „Jesteście u nas mile widziani!” (...) W Polsce nie ma zgody na rasizm"3. Politycy lewicowi zdecydowanie popierają imigrację, odwołując się do humanistycznych i uniwersalnych wartości.

\section{Przykłady mowy nienawiści w dyskursie o migracji}

Liczne manifestacje wywołały panikę medialną, która była tłem do wyborów parlamentarnych w $2015 \mathrm{r}$. Media inicują i rozdmuchują tę panikę. Media prawicowe przedstawiają problem uchodźców jako zagrożenie dla wartości i interesów społecznych, zagrożenie dla religii chrześcijańskiej w Europie. Dlatego w dyskursie prawicowym widoczna jest stereotypizacja uchodźców. Dzieje się tak, ponieważ stanowisko negatywne popierają autorytety moralne, naukowe, społeczne, np. profesorowie, redaktorzy, księża, politycy, którzy wypowiadają sądy stygmatyzujące i wykluczające. Ich krytyka znajduje naśladowców w internecie, stąd pełno komentarzy o jawnych poglądach antyimigranckich w polskim społeczeństwie. Widać to w bezwzględnych komentarzach.

Korpus badawczy tworzą przykłady pochodzące $\mathrm{z}$ internetu, wśród których są wypowiedzi bardzo pozytywne, jak i bardzo negatywne. To szerokie spektrum poglądów i postaw udało się uzyskać dzięki uwzględnieniu tytułów czasopism online o zróżnicowanym profilu politycznym, zarówno prawicowym, lewicowym, jak i liberalnym (m.in. „Sieci”, „Polityka”, „Newsweek”), jak również dzięki komentarzom pod artykułami z tych czasopism. Kryterium doboru korpusu była aktualność i istotność poruszonej problematyki oraz możliwość generalizacji wyników badań. Sformułowania użyte w podanych przykładach są reprezentatywne dla danej grupy poglądów, jednoznacznie przedstawiają dany światopogląd, nie pozostawiając niedomówień. Przy internetowych wydaniach czasopism użytkownicy mają większą swobodę wypowiedzi niż w przypadku tradycyjnych form tych czasopism. Często też są to wypowiedzi anonimowe, co zwiększa odwagę w wyrażaniu silnych, ekstremalnych emocji, doświadczanych przez poszczególnych uczestników dyskursu. Zaprezentowane przykłady z komentarzy posiadają zazwyczaj wyższą temperaturę emocjonalną niż fragmenty tekstu źródłowego.

Korpus badawczy został ustalony na podstawie wybranych czasopism online. Pierwszym etapem procesu badawczego był wstępny przegląd tytułów i tekstów. W wybranych czasopismach zostały zidentyfikowane fragmenty wyrażające pozytywny lub negatywny stosunek do migracji. Następnie przykłady wyrażające negatywny stosunek, uznane za przykłady mowy nienawiści zostały uporządkowane począwszy od uzasadnionej versus nieuzasadnionej krytyki, przez niechęć, właściwą mowę nienawiści po ekstremalną mowę nienawiści

3 Pełny tekst odezwy można przeczytać na: http://krytykapolityczna.pl/kraj/ 15-pazdzier-nika-dzien-solidarnosci-z-uchodzcami/ [Dostęp: 8.11.2020]. 
(Majewska-Zarychta 2019: 34-42). Do analizy końcowej trafily wyłącznie przykłady wyrażające ekstremalną mowę nienawiści, a z drugiej strony przykłady wyrażające ciepłą i akceptującą postawę w stosunku do migracji. Jak widać poniżej, przykłady ekstremalnej mowy nienawiści są wyrażane pod względem składniowym przez tryb rozkazujący, który wiąże się często z nawoływaniem do agresji fizycznej. Pod względem semantycznym są wyrażane za pośrednictwem neologizmów i wulgaryzmów. Widać to na następujących przykładach:

„Można by otworzyć Auschwitz na nowo dla imigrantów i do tego podciągnąć nową instalację gazową” - pisze na Facebooku Kuba (Wieliński 2015).

"Czekamy na przyjazd emigrantów, z racji ukończonej szkoły będę zajmował się konserwacją komór gazowych. Emigranci, zapraszamy, drzwi otwarte, wstęp bezpłatny (bilet w jedną stronę)”. - pisze na Facebooku Michał".

„Cała Polska dzisiaj krzyczy: „nie” dla tej islamskiej dziczy!”

„Rozstrzelać” to „czarne ścierwo”, „zrobić z nich tanią podpałkę”. „Nie jestem rasistą, ale nienawidzę tych kozojebców”. „Zebrać wszystkich w jedną kupę, cyklon B i po sprawie, świat znów byłby piękny"

Przykłady te wyrażają chęć doprowadzenia do jawnej eksterminacji uchodźców.

Maciej Gajek podsumowuje taką mowę nienawiści w sposób następujący:

„Nie chcemy imigrantów”. Europa zamyka się i brunatnieje. Problem uchodźców to na razie w Polsce kwestia wyłącznie polityczna. Ale mamy gorszy, realny kłopot: kiełkujący rasizm. (...) Uchodźcy przestają być problemem tak wielkim, jak staje się europejska ( w tym polska) nienawiść do muzułmanów. Co bardziej przerażające - ulega jej nawet Kościół Rzymskokatolicki

Funkcjonuje tu zasada generalizacji. Jak w przypadku pedofilli pojawił się stereotyp, że „każdy ksiądz to pedofil”, tak w przypadku uchodźców „każdy muzułmanin to terrorysta".

Witold Gadowski, dziennikarz i reporter, uchodzący również za „znawcę krajów arabskich i uchodźców", porównał uchodźców do toksycznych odpadów:

Nie możemy przyjmować tych migrantów, których przyśle nam Unia Europejska. (...) Obecnie Unia będzie się starała pozbywać najbardziej toksycznych

${ }^{4}$ Wzywali, by wysyłać uchodźców do Auschwitz-Birkenau. Zajmie się nimi prokuratura, https://wiadomosci.wp.pl/wzywali-by-wyslac-uchodzcow-do-obozu-auschw itz-birkenau-zajmie-sie-nimi-prokuratura-6025255149995137a [Dostęp: 11.12.2019].

${ }^{5}$ Jak łatwo jest pomagać uchodźcom, https://www.newsweek.pl/polska/kryzys-m igracyjny-jak-polacy-pomagaja-syryjskim-uchodzcom/3nmgs4k [Dostęp: 15.12.2019].

6 "Nie chcemy imigrantów”. Europa zamyka się i brunatnieje, https://www.new sweek.pl/opinie/uchodzcy-w-europie-rasizm-w-polsce-imigranci/nkyylw9 [Dostęp: 12.12.2019].

${ }^{7}$ Ibidem [Dostęp: 12.12.2019]. 
elementów ze swojego społeczeństwa, wysyłając ich do Polski. Nie możemy się biernie godzić na to, co Unia nam podyktuje. Musimy mieć rozumną politykę .

Brytyjska organizacja pozarządowa Runnymede Trust25 w 1997 r. opublikowała raport, obejmujący poglądy, które są podstawą islamofobii (Pasamonik i Markowska-Manista 2017: 36):

- islam stanowi niepodatny na zmiany monolit;

- islam jest całkowicie odrębny i „obcy”, nie ma zatem nic wspólnego z kulturą Zachodu;

- islam jest gorszy (barbarzyński, nieracjonalny, prymitywny, seksistowski) od religii i kultury Zachodu;

- islam jest groźny, nie stroni bowiem od przemocy, agresji i terroryzmu;

- islam jest ideologią polityczną, podatną na manipulację, nadużywaną do celów politycznych i militarnych.

Obok postawy negatywnej i stereotypowej widoczna jest postawa wspólczująca. Postawa współczująca, wyrażająca empatię w stosunku do uchodźców uwzględnia ich indywidualne losy, ich specyficzną sytuację ze względu na wojnę, biedę, utratę bliskich, domu i ojczyzny. W przeciwieństwie do postawy wspólczującej, postawa odrzucająca neguje człowieczeństwo uchodźców. Według niej uchodźcy są przyczyną terroryzmu, gwałtów na kobietach europejskich, przestępstw i przemocy. Widoczna tu niechęć opiera się na braku zaufania do osób odmiennych kulturowo i religijnie. Uchodźcy są traktowani jako imigranci ekonomiczni. Zatem nie należy im pomagać. Jak pisze Barbara Panasińska (2018: 38), w postawie proimigracyjnej europejskie społeczeństwo jest otwarte na inność, a w przypadku postawy antyimigracyjnej Europa to oblężona twierdza, gdzie dokonuje się zderzenie cywilizacji. Społeczeństwo europejskie jest społeczeństwem ekskluzywnym, chrześcijaństwo stoi w opozycji do islamu: albo chrześcijaństwo albo islam, a Polska jest przedmurzem chrześcijaństwa. W obydwu obrazach uchodźcy widoczne są elementy poznawcze i emocjonalne. Postawa współczująca opiera sie na empatii, schematem poznawczym są biedni ludzie, uciekający przed wojną. Postawa negatywna opiera się na lęku i zagrożeniu, a dominujący schemat poznawczy jest następujący: uchodźcy to potencjalni terroryści, radykalni islamiści lub oszuści podszywający się pod uchodźców i zagrażający bezpieczeństwu Polaków. Te dwa poglądy reprezentowane są przez grupy: prawdziwi chrześcijanie, altruiści contra prawdziwi patrioci, odpowiedzialni za przyszłość Polaków i Polski. Środowisko liberalne związane z lewicą i środowisko

8 Gadowski z Syrii: Nie możemy przyjmować migrantów, których przyśle nam UE. To będzie jak z odpadami toksycznymi w latach 90., https://wpolityce.pl/polity ka/259240-gadowski-z-syrii-nie-mozemy-przyjmowac-migrantow-ktorych-przysle -nam-ue-to-bedzie-jak-z-odpadami-toksycznymi-w-latach-90-nasz-wywiad [Dostęp: 12.12.2019]. 
konserwatywne związane z prawicą walczą o dominację ich obrazu uchodźcy. Osoby reprezentujące lewicowe poglądy traktują problem imigracji jako wyzwanie (Pasamonik i Markowska-Manista 2017: 38). Jerzy Nikitorowicz (2013: 42) pisze o otwartości na imigrantów:

Z pewnością należałoby zauważyć świat wspólnych wartości związanych z uniwersalizmem anatomofizjologicznym, psychologicznym i społecznym. Inaczej mówiąc, należałoby ustawicznie rozszerzać postawę otwartości na inność, tolerancji, uznania, empatii w celu nabywania umiejętności korzystania z kilku układów kulturowych, umiejętności postrzegania Innych i odnoszenia się do nich z pozycji różnych odniesień kulturowych. (Nikitorowicz 2013: 43).

Stawianie znaku równości pomiędzy islamem a terroryzmem oraz pomiędzy islamem a religią fundamentalizmu jest niesprawiedliwe. Jednak jakie skutki przyniesie przyjazd tak ogromnej liczby ludności z innych kontynentów, okaże się za wiele lat. Profesor KUL Mieczysław Ryba stwierdza już teraz: „Podstawowe pytanie, jakie się jawi, dotyczy postawy polskiego Narodu. To my mieliśmy rację w sprawie imigrantów, nie Unia" (Ryba 2015). Wiąże się to z przekonaniem o nieomylności Polaków.

\section{Podsumowanie}

Podsumowując, należy stwierdzić, że zjawisko migracji jest złożone i wyzwala różne postawy, jak zaprezentowano w niniejszym artykule. Dwubiegunowość postaw jest widoczna $w$ dyskursie na różnych poziomach językowych, poczynając od wypowiedzi wziętych z języka codziennego, poprzez język medialny, aż po język elit intelektualnych. Niniejszy artykuł jest próbą zaprezentowania wyżej omówionych postaw. Polaryzacja społeczeństwa jest pogłębiana poprzez wspominaną panikę medialną. Jak zostało powiedziane, media są katalizatorem lęku społecznego. W jednych środowiskach dominuje strach i niechęć, ksenofobia i rasizm, a w innych skrajny liberalizm, ukrywanie prawdziwych zdarzeń, bagatelizowanie faktów. W takiej atmosferze Polacy nie są grupą jednomyślną. Z jednej strony chcą pomagać, a $\mathrm{z}$ drugiej wykluczać. Ta niechęć do niesienia pomocy może wynikać częściowo z informacyjnego efektu negatywności, zgodnie z którym informacje negatywne są latwiej zapamiętywane niż pozytywne. W związku z tym wśród Polaków następuje wzrost poglądów i postaw antyimigracyjnych. Dynamika procesów migracyjnych będzie w najbliższej przyszłości umacniała ich siłę i zakres, co z pewnością będzie prowadziło do wzmocnienia opisanej $\mathrm{w}$ artykule dychotomii dyskursu zaangażowanych grup społecznych, a to jest zjawiskiem bardzo ciekawym z językoznawczego punktu widzenia, ale jednocześnie będzie prowadzić do niebezpiecznego wzrostu napięć społecznych - dynamiki procesów językowych i społecznych, które są zawsze ze sobą sprzężone. 


\section{Bibliografia}

Aronson, Elliot (2009), Człowiek istota społeczna. Warszawa.

Błeszyńska, Krystyna (2013), Komunikacja międzykulturowa jako negocjowanie znaczeń. W: „Pogranicza. Studia Społeczne” Tom XXI, nr 21, s. 139-154.

Ceranek-Dadas, Anna; Neumann-Schmidtke, Elżbieta (2005), Postawy. W: Pilch, Tadeusz (red.), Encyklopedia pedagogiczna XXI wieku Tom 4. Warszawa, s. 743-749.

Domosławski, Artur (2017), Wykluczeni. Warszawa.

Fidelus, Anna (2011), Podstawy społeczne jako element kapitału spotecznego a proces readaptacji społecznej skazanych. W: „Forum Pedagogiczne UKSW” nr 1, s. 87-124.

Mądrzycki, Tadeusz (1977), Psychologiczne prawidłowości kształtowania się postaw. Warszawa.

Majewska-Zarychta, Joanna (2019), Mowa nienawiści we wspótczesnych mediach. Przykłady i konsekwencje jej stosowania. W: „Kwartalnik edukacyjny” nr 3 (98), s. 26-43.

Markowska-Manista, Urszula; Zakrzewska-Olędzka, Dominika (2017), Pomiędzy teoria a praktyka kontaktu międzykulturowego. W: „Pogranicze. Studia Społeczne” Tom XXX, s. 113-129.

Nikitorowicz, Jerzy (2013), Tożsamość - twórczy wysitek ku patriotyzmowi. W: Nikitorowicz, Jerzy (red.), Patriotyzm i nacjonalizm. Ku jakiej tożsamości kulturowej? Kraków, s. 29-42.

Nelson, Tood D. (2003), Psychologia uprzedzeń. Gdańsk.

Papież Franciszek (2015), Laudato si. Kraków.

Orzechowski, Marek (2018), Chaos. Nowy porzadek świata. Warszawa.

Pasamonik, Barbara; Markowska-Manista, Urszula (red.) (2017), Kryzys migracyjny. Perspektywa społeczno-kulturowa Tom I. Warszawa.

Pospiszyl, Irena (2008), Patologie Społeczne. Warszawa.

Ryba, Mieczysław (2015), Międzynarodowa nagonka. W: „Nasz Dziennik”, 12-13 grudnia.

\section{Źródła internetowe}

Domosławski, Artur; Gostkiewicz, Michał. Domosławski: My Polacy przeskoczyliśmy do Pierwszego Świata. Jesteśmy krezusami. Nie chcemy się dzielić, http://weekend.ga zeta.pl/weekend/1,152121,19877975,domoslawski-my-polacy-przeskoczylismy-d o-pierwszego-swiata.html [Dostęp: 15.12.2019].

Kapela, Jaś. 11 powodów dla których powinniśmy przyjąć więcej uchodźców, https://kryty kapolityczna.pl/felietony/jas-kapela/11-powodow-dla-ktorych-powinnismy-przyj ac-wiecej-uchodzcow/ [Dostęp: 15.12.2019].

Ks. Prof. Paweł Bortkiewicz, Ks. Bortkiewicz na premierze filmu „Mięsożercy”: weganizm to już nie dieta, tylko oferta ideologiczna, https://www.pch24.pl/ks_bortkiewicz-n a-premierze-miesozercy—weganizm-to-juz-nie-dieta-tylko-oferta-ideologiczna, 72427,i.html [Dostęp: 30.11.2019].

Marcin Jędrzejczak, Ekoreligia - ponure wypaczenie chrześcijaństwa, https://www.pch24 .pl/ekoreligia-ponure-wypaczenie-chrzescijanstwa-pch,69793,i.html utm_sour ce $=$ facebook\&utm_medium $=$ social\&utm_campaign $=$ post\&utm_term $=$ pch $[$ Dostęp: 12.12.2019]. 
Olga Tokarczuk: Wstyd mi, że Polska nie przyjęła imigrantów, https://www.wp.pl/?s=htt ps\%3A\%2F\%2Fwiadomosci.wp.pl\%2Folga-tokarczuk-wstyd-mi-ze-polska-nie-prz yjela-imigrantow-6455637527635585a\&nil [Dostęp: 11.12.2019].

Piasecki, Konrad Tomczyk: 12 tys. uchodźców w Polsce to sprawiedliwe, ale jesteśmy przygotowani na każdą liczbę https://www.rmf24.pl/tylko-w-rmf24/wywiady/kontrw ywiad/news-tomczyk-12-tys-uchodzcow-w-polsce-to-sprawiedliwe-ale-jestes,nId, 1887964 [Dostęp: 05.12.2019].

Samoniuk, Barbara, "Malowanie strasznego diabta” - metamorfoza obrazu uchodźcy w Polsce, https://www.academia.edu/36061344/_Malowanie_strasznego_diab\%C5\%8 2a_-_metamorfoza_obrazu_uchod\%C5\%BÄcy_w_Polsce [Dostęp: 10.12.2019]. Wieliński, T. Bartosz. Hejter polski: Auschwitz to idealny pensjonat dla Syryjczyków, https://wyborcza.pl/1,75968,18713459,hejter-polski-auschwitz-to-idealny-pensjon at-dla-syryjczykow.html [Dostęp: 10.12.2019].

\title{
Joanna Majewska-Zarychta \\ Bipolarity of attitudes towards the phenomenon of migration and their reflection in the language of media discourse
}

\begin{abstract}
This article presents the attitudes of persons who are friendly and unfriendly towards migration phenomenon. These attitudes are on two opposite poles, from extremely positive to extremely negative. Both in everyday language as well as in the media language or the language of the elite one can notice this outlined bipolarity of attitudes. The article discusses the definition of attitude as an element of intercultural communication that shapes relationships on the international stage. The pro and contra arguments present the complexity of the migration phenomenon. Contra arguments are reinforced by stereotypes about migrants, which were described using examples from the media. The evidence of a strong polarization of attitudes and above all a negative attitude towards migration is given by numerous examples of hate speech in socio-political discourse. It appears in both liberal, leftist and rightist magazines. This phenomenon seems interesting from a linguistic point of view, but one needs to know that it is associated with various social tensions which also affect language.
\end{abstract}

Keywords: attitude, migration, hate speech, stereotype, discourse

Słowa kluczowe: postawa, migracja, mowa nienawiści, stereotyp, dyskurs 